\title{
ALLELOPATHIC EFFECTS OF BLACK NIGHTSHADE (SOLANUM NIGRUM L.) ON GERMINATION, GROWTH AND YIELD OF BROAD BEAN (VICIA FABA L.) AND COMMON BEAN (PHASEOLUS VULGARIS L.)
}

\author{
ISMAIEL, S. A.* - SALAMA, H. M. \\ Botany and Microbiology Department, Faculty of Science, Zagazig University, Zagazig 44519, \\ Egypt \\ *Corresponding author \\ e-mail:sh_botanist2010@yahoo.com; phone: +20-111-244-2705 \\ (Received $13^{\text {th }}$ Apr 2021; accepted $19^{\text {th }}$ Jul 2021)
}

\begin{abstract}
Germination tests and pot experiments were conducted to explore the allelopathic effect of aqueous extracts of S. nigrum on germination, growth and yield of Vicia faba (L.) and Phaseolus vulgaris (L.). Ten treatments including control were prepared by using extracts obtained from different parts of $S$. nigrum, including roots, leaves, and seeds at 3 concentrations (10, 40, and 60\%) to conduct the germination test. The pot experiment was studied by incorporating powder of different plant parts into the soil at 3 concentrations $(0.5,1$, and $1.5 \%)$. The results of the germination test revealed that the aqueous extracts of roots and leaves significantly reduced germination percentage, radicle, and plumule length of both beans. There was a direct negative relationship between germination test and the plant parts used, including their concentrations. However, seed extract showed a non-significant difference $(p>0.05)$. In the pot experiment, different powders of black nightshade incorporated into the soil decrease plant height, root length, fresh and dry weights. However, the number of leaves was not affected. Also, yield components were decreased with the highest concentrations used. The reduction of germination, growth, and yield of the broad and common beans increased with higher concentrations of root and leaf aqueous extracts, while that of seeds had limited effect. The strongest allelopathic effect of broad and common beans was caused by root extracts of the highest concentration.
\end{abstract}

Keywords: aqueous extract, germination test, pot experiment, plant height, yield components

\section{Introduction}

Allelopathy is a form of interaction between plants, exerted through a chemical inhibitor produced by a plant helping to intervene in the growth and development of another one (Zeng et al., 2010). These chemicals with allelopathic potential can be released into the environment, under suitable conditions, in sufficient amounts to affect neighboring plants (Tahir, 2011). Allelopathy has beneficial or harmful effects on plants due to the release of allelochemicals which are secondary metabolites, which are present in all plant tissues including leaves, stems, flowers, roots, and seeds (Mohsin et al., 2016).

Solanaceae plants have the ability of allelopathy, and so that the species of plants control the behavior, form, and amount of allelopathic compounds (Mushtaq and Siddiqui, 2018). The genera of this family, Withania, Solanum, Iochroma, Nicotiana, and Datura are rich sources of sesquiterpenoid phytoalexins (Elakovich, 1987). The toxic alkaloids present in certain species of the family have given it its vernacular name of nightshade. The genus Solanum is massive, contains species distributed in many parts of the world. The non-growth or growth depletion of neighboring plants is caused by allelopathic constituents of this genus (Mushtaq and Siddiqui, 2018). The phenomena have been found in the two biologically active glycoalkaloids, solasonine, and 
solamargine (Fukuhara and Kubo, 2004). Solanum nigrum (L.) is a common and troublesome annual weed in many parts of the world, it is one of the most widespread species in Solanaceae family. S. nigrum is a common plant due to its toxic content of Solanine, a glycoalkaloid found in most parts of the plant, with the highest concentrations in the unripened berries (Imad et al., 2017). Although it is considered a rich source of one of the most popular plant poisons, it has also proven to be a pharmacologically prospective reservoir of phytochemicals. Leaves and berries of $S$. nigrum are commonly used in South India for the treatment of gastric ulcers, gastritis, and other gastric problems (Hadi et al., 2017; Chen et al., 2009).

Considering the economic importance, and nutritional facts of leguminous crops, broad and common beans in the world especially in developing countries. The article aimed to determine the effect of aqueous extracts obtained from different parts of the black nightshade, at various concentrations, on the germination, growth and yield of common and broad beans cultivated in Egypt, to assess the plant's allelopathic potential.

\section{Materials and methods}

\section{Site of experiments}

Two experiments were conducted to study the allelopathic effect of different parts of $S$. nigrum, including germination test and pot experiment. The germination test was carried out in the laboratory of Plant Ecology, Faculty of Science, Zagazig University, Egypt. The pot experiment was carried out in the greenhouse of the faculty under field conditions.

\section{Plant collection}

Matured black nightshade was collected at the fruiting stage from an agricultural field west of Zagazig University. The plant was separated into roots, leaves, and seeds then oven-dried and ground into a fine powder using mortar. Broad bean ( $V$. faba) and common bean (Ph. vulgaris) seeds were obtained from Agricultural Research Centre, Egypt.

\section{Chemical analysis}

Quantitative estimation of the four major active principles in root, leaf, and seed powders of black nightshade was carried out. Total alkaloid and saponin were determined according to Obadoni and Ochuko (2001). Total flavonoid content was estimated by the method of Srisawat et al. (2010) and tannin according to Edeoga et al. (2005).

\section{Germination test}

This experiment was conducted to explore seed germination, length of the radicle, and plumule of beans under the effect of aqueous extract of roots, leaves, and seeds of black nightshade. Aqueous extract of different plant parts was prepared by adding $20 \mathrm{~g}$ of the dried part to $800 \mathrm{ml}$ of distilled water, then put in a magnetic stirrer for $24 \mathrm{~h}$. The extracts were filtered (stock solutions) and stored at $4{ }^{\circ} \mathrm{C}$ until use later. From each stock solution, three concentrations were prepared by dilution method (10, 40, and $60 \%$ ), these concentrations were selected depending on a previous study (Stef et al., 2013). 
Ten seeds of both beans were put sparsely in a filter paper covered glass petri dish (10 seeds/petri dish). Each dish was applied by $5 \mathrm{ml}$ aqueous extract of each plant part, whereas $5 \mathrm{ml}$ distilled water was applied to the control. The treatments were arranged with three replicates in a fully randomized system. The petri dishes were kept in the laboratory at room temperature for 10 days, the germinated seeds were counted to calculate the germination percentage, and the length of radicle and plumule were measured.

\section{Pot experiment}

The pots used were $30 \mathrm{~cm}$ in diameter, and $30 \mathrm{~cm}$ high filled with equal amounts of sieved soil (2:1 v/v clay and sand). The soil was incorporated with 10, 20, and $30 \mathrm{~g}$ of plant parts powder representing $0.5,1$, and $1.5 \%$ (residue/soil, w/w) respectively. Soil without $S$. nigrum residue represented control. Each pot was planted with 5 seeds of broad and common beans. After emergence, the seedlings were thinned to 3 seedlings per pot. The pots were kept free from weeds and irrigated uniformly. Each treatment was replicated 3 times and pots were distributed in a complete randomized design. At 30 days after sowing, growth parameters like plant height, root length, number of leaves, fresh, and dry weights of plants were recorded. At harvest broad and common beans were taken to determine the yield components like the number of pods/plant, number of seeds/pod, and weight of 100 seeds $(\mathrm{g})$.

\section{Statistical analysis}

Data were statistically analyzed using SPSS program version 23 . The averages of different groups and standard error were calculated. The two-way ANOVA test was performed for comparison between the different studied factors (i.e., Aqueous extract and treatments) and followed by post hoc test using Duncan multiple range (DMR) test for comparisons between means of groups. The means followed by the same letter in each column are not significantly different from each other at the 5\% probability level ( $\mathrm{p}$ value at 0.05 )

\section{Results}

Chemical analysis of black nightshade revealed the presence of many bioactive secondary metabolites in all parts of this plant, particularly alkaloids which are responsible for suppressing the growth of other plants (Table 1).

Table 1. Chemical constituents in different parts of black nightshade

\begin{tabular}{c|c|c|c|c}
\hline \multirow{2}{*}{ Plant parts } & \multicolumn{4}{|c}{ Content (\%) } \\
\cline { 2 - 5 } & Alkaloid & Flavonoid & Tannin & Saponin \\
\hline Roots & 1.68 & 0.73 & 0.14 & 0.30 \\
Leaves & 1.39 & 0.88 & 0.16 & 0.28 \\
Seeds & 0.962 & 0.49 & 0.13 & 0.27 \\
\hline
\end{tabular}

There was no significant difference between the two leguminous plants in their response to residue and extract of the allelopathic plant for all parameters recorded. 


\section{Germination test}

The results presented in Figures 1 and 2 showed clearly the effects of different aqueous extracts of black nightshade, different treatments, and interaction effects on germination percentage, and length of radicle and plumule of beans. These parameters significantly $(\mathrm{p} \leq 0.05)$ decreased after being treated with roots and leaves aqueous extracts of black nightshade. However, the reduction in these parameters increased with the concentration of aqueous extracts, and depend on the part used in the extract. According to the displayed data, aqueous extract of seeds was found to be non-significant $(\mathrm{p}>0.05)$ for all parameters. The highest inhibitory effects were exhibited by root extract particularly at $60 \%$ concentration, compared to control. The lowest seed germination and length of radicle and plumule of broad bean were $68.2 \%, 2.80 \mathrm{~cm}$, and $3.65 \mathrm{~cm}$ respectively for aqueous root extract (Fig. 1 $a, b, c)$. In common beans, seed germination and length of radicle and plumule significantly lowered to $84.31 \%, 3.08 \mathrm{~cm}$, and $4.36 \mathrm{~cm}$ respectively for those treated with root extract (Fig. $2 a, b, c)$.
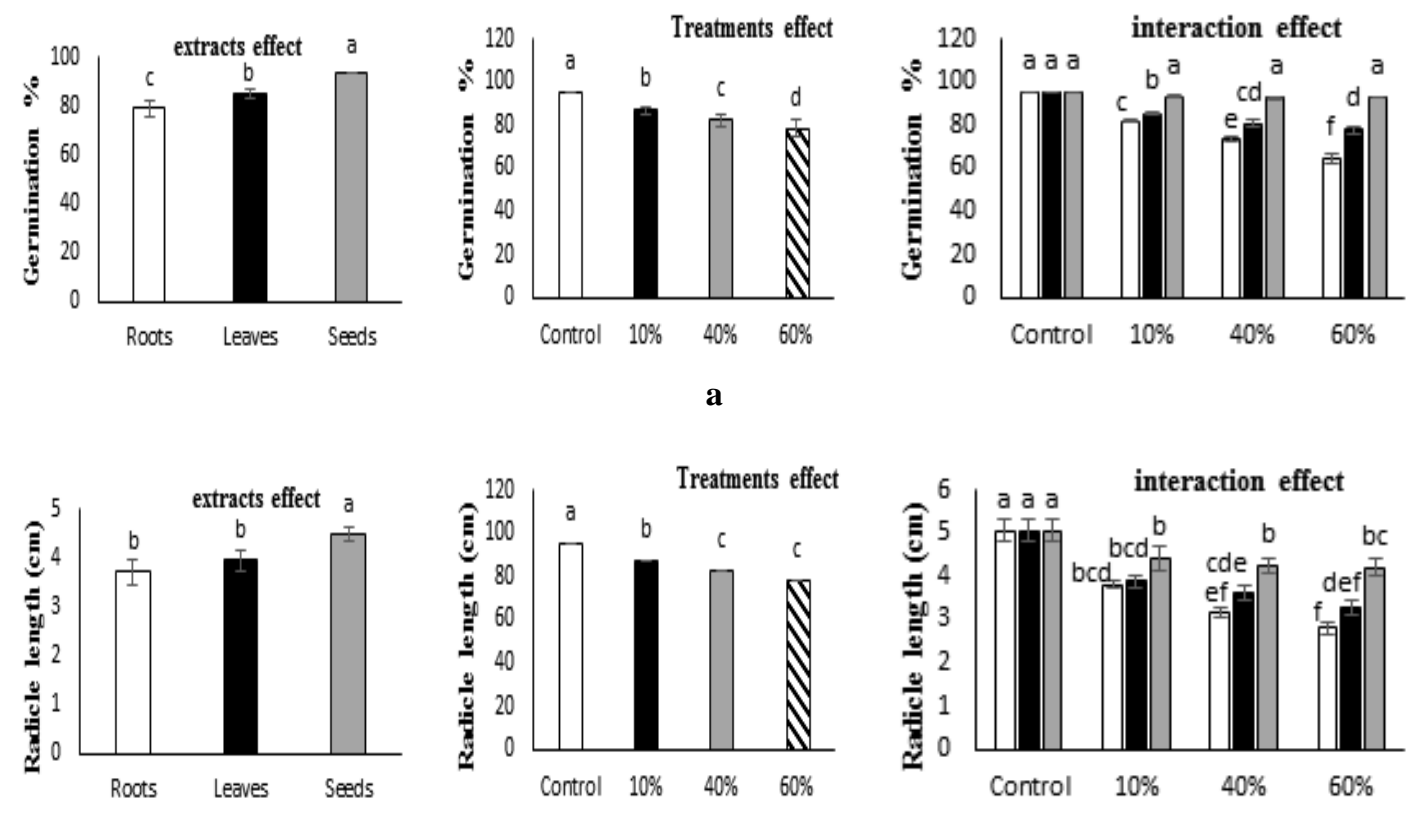

b
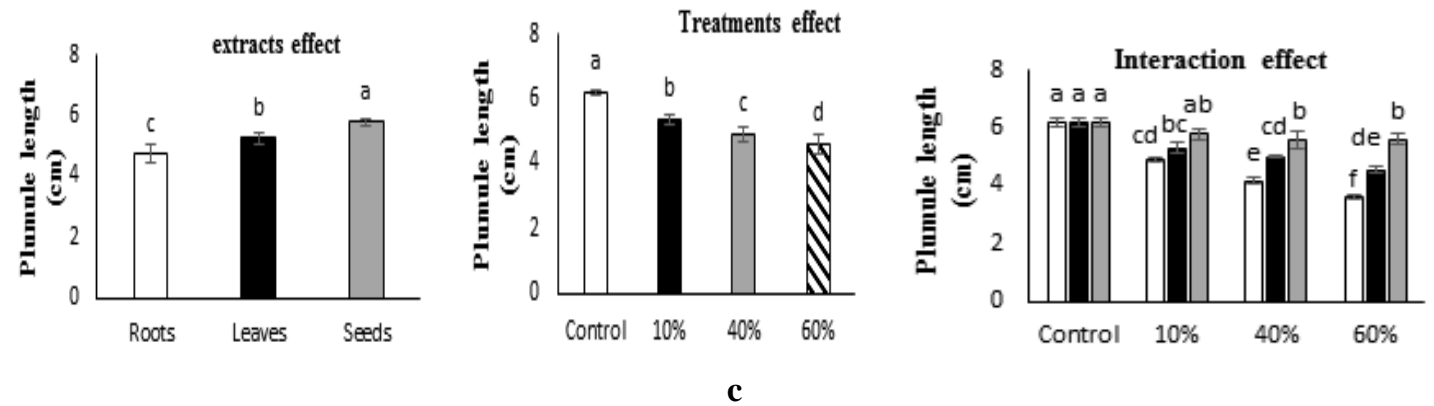

Figure 1. Effects of black nightshade aqueous extracts, different treatments and interaction effect on broad bean, a: germination percent (\%); $b$ : radical length (cm); $c$ : plumule length $(\mathrm{cm})$. Error bars indicating the standard error $(S E)$ of three replicates, are significantly $* P<0.05$ 

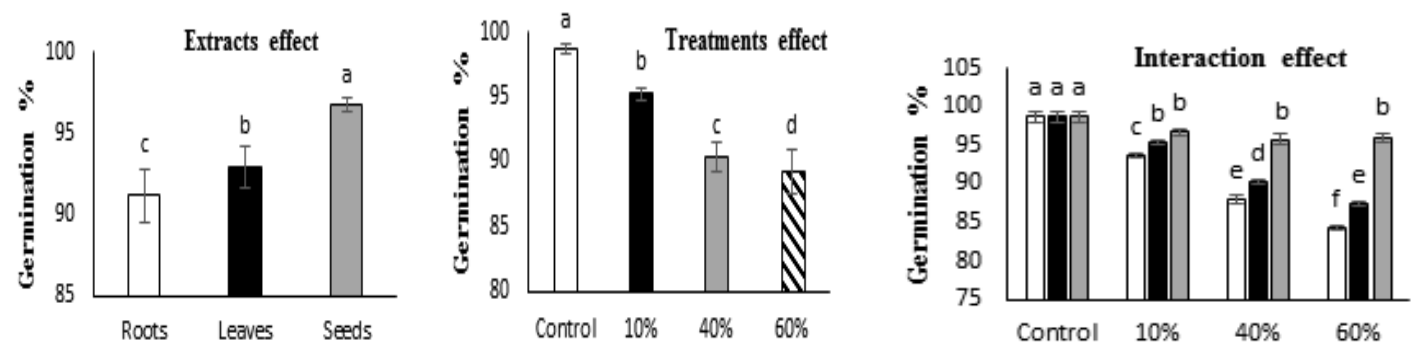

$\mathbf{a}$
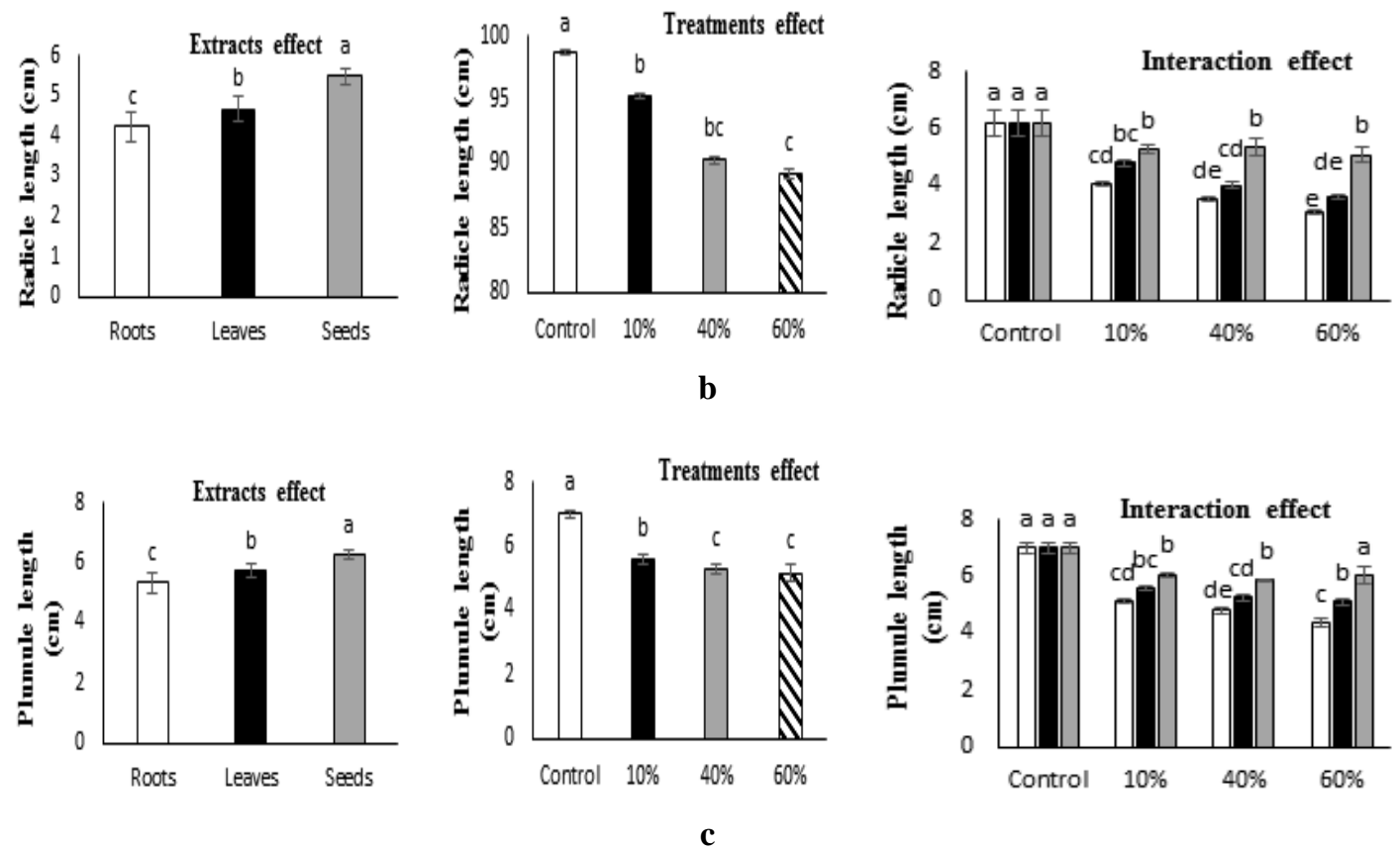

Figure 2. Effects of black nightshade aqueous extracts, different treatments and interaction effect on common bean, a: germination percent (\%); $b$ : radical length $(\mathrm{cm}) ; c$ : plumule length $(\mathrm{cm})$. Error bars indicating the standard error $(S E)$ of three replicates, are significantly $* P<0.05$

\section{Pot experiment}

The results presented in Table 2 and 3 showed the effect of root, leaf, and seed powders incorporated into the soil on growth parameters of beans. All parameters investigated in this study except the number of leaves significantly $(p \leq 0.05)$ decreased in both plants treated with different powders of black nightshade.

Relative to control, plant height of both beans significantly decreased, and this reduction was increased as different powders increased in the soil. The greatest reduction in plant height was observed when root powder was added to the soil at $1.5 \%$. The plant height of the broad bean lowered to $27.05 \mathrm{~cm}$ (Table 2) and the common bean decreased to $26.1 \mathrm{~cm}$ (Table 3).

The data of root length showed the same trend of plant height, the greatest reduction in root length was recorded when root powder was incorporated into the soil. The root length of broad and common beans in control was 16.23 and $16.53 \mathrm{~cm}$, respectively. The root length decreased to $10.06 \mathrm{~cm}$ in the broad bean, and $13.07 \mathrm{~cm}$ in the common bean $(\mathrm{p} \leq 0.05)$. 
Table 2. Growth parameters of broad bean under the effect of different concentrations of black nightshade residues

\begin{tabular}{c|c|c|c|c|c}
\hline $\begin{array}{c}\text { Treatments } \\
(\%)\end{array}$ & $\begin{array}{c}\text { Plant height } \\
(\mathbf{c m})\end{array}$ & $\begin{array}{c}\text { Root length } \\
(\mathbf{c m})\end{array}$ & $\begin{array}{c}\text { Fresh wt. } \\
(\mathbf{g})\end{array}$ & $\begin{array}{c}\text { Dry wt. } \\
(\mathbf{g})\end{array}$ & Leaves no. \\
\hline R 0.5 & $29.58 \pm 0.32 \mathrm{ef}$ & $12.03 \pm 0.03 \mathrm{fg}$ & $7.44 \pm 0.22 \mathrm{de}$ & $2.19 \pm 0.13 \mathrm{fg}$ & $10 \pm 0.33 \mathrm{a}$ \\
R 1 & $28.55 \pm 0.22 \mathrm{~g}$ & $10.75 \pm 0.25 \mathrm{~h}$ & $6.64 \pm 0.17 \mathrm{f}$ & $1.81 \pm 0.12 \mathrm{~g}$ & $9.66 \pm 0.57 \mathrm{a}$ \\
R 1.5 & $27.05 \pm 0.12 \mathrm{~h}$ & $10.06 \pm 0.08 \mathrm{~h}$ & $6.01 \pm 0.01 \mathrm{~g}$ & $1.13 \pm 0.08 \mathrm{~h}$ & $9.66 \pm 0.33 \mathrm{a}$ \\
Mean & $30.09 \pm 3.09 \mathrm{c}$ & $12.27 \pm 2.51 \mathrm{c}$ & $7.41 \pm 1.45 \mathrm{c}$ & $2.226 \pm 1.03 \mathrm{c}$ & $9.91 \pm 0.67 \mathrm{a}$ \\
L 0.5 & $31.33 \pm 0.33 \mathrm{~d}$ & $13.58 \pm 0.25 \mathrm{~d}$ & $8.12 \pm 0.11 \mathrm{c}$ & $3.02 \pm 0.03 \mathrm{~cd}$ & $10 \pm 0.57 \mathrm{a}$ \\
L 1 & $30.18 \pm 0.12 \mathrm{e}$ & $12.50 \pm 0.28 \mathrm{ef}$ & $7.98 \pm 0.02 \mathrm{~cd}$ & $2.66 \pm 0.07 \mathrm{de}$ & $10 \pm 0.33 \mathrm{a}$ \\
L 1.5 & $29.35 \pm 0.19 \mathrm{f}$ & $11.54 \pm 0.23 \mathrm{~g}$ & $7.11 \pm 0.11 \mathrm{ef}$ & $2.28 \pm 0.08 \mathrm{ef}$ & $9.66 \pm 0.33 \mathrm{a}$ \\
Mean & $31.42 \pm 2.22 \mathrm{~b}$ & $13.46 \pm 1.87 \mathrm{~b}$ & $8.19 \pm 0.97 \mathrm{~b}$ & $2.933 \pm 0.6 \mathrm{~b}$ & $10.00 \pm 0.74 \mathrm{a}$ \\
S 0.5 & $34.50 \pm 0.28 \mathrm{ab}$ & $15.51 \pm 0.28 \mathrm{ab}$ & $9.01 \pm 0.09 \mathrm{ab}$ & $3.32 \pm 0.16 \mathrm{ab}$ & $10.33 \pm 0.66 \mathrm{a}$ \\
S 1 & $33.94 \pm 0.05 \mathrm{ab}$ & $14.50 \pm 0.28 \mathrm{ab}$ & $8.80 \pm 0.1 \mathrm{ab}$ & $3.05 \pm 0.05 \mathrm{bc}$ & $10.33 \pm 0.33 \mathrm{a}$ \\
S 1.5 & $32.31 \pm 0.33 \mathrm{c}$ & $12.77 \pm 0.39 \mathrm{bc}$ & $8.06 \pm 0.03 \mathrm{~cd}$ & $2.80 \pm 0.11 \mathrm{~d}$ & $10.30 \pm 0.66 \mathrm{a}$ \\
Mean & $33.90 \pm 1.08 \mathrm{a}$ & $14.75 \pm 1.43 \mathrm{a}$ & $8.86 \pm 0.63 \mathrm{a}$ & $3.231 \pm 0.44 \mathrm{a}$ & $10.33 \pm 0.78 \mathrm{a}$ \\
Control & $34.84 \pm 0.31 \mathrm{a}$ & $16.23 \pm 0.17 \mathrm{ab}$ & $9.58 \pm 0.34 \mathrm{a}$ & $3.75 \pm 0.23 \mathrm{ab}$ & $10.33 \pm 0.33 \mathrm{a}$ \\
\hline
\end{tabular}

Mean \pm standard error based on ANOVA analysis. Means in the same raw followed by the same letter in each column are not significantly different from each other at the 5\% probability level ( $\mathrm{p}$ value at $0.05)$ according to Duncan Multiple Range Test (DMRT). R: root; L: leaf; S: seed

Table 3. Growth parameters of common bean under the effect of different concentrations of black nightshade residues

\begin{tabular}{c|c|c|c|c|c}
\hline $\begin{array}{c}\text { Treatments } \\
(\%)\end{array}$ & $\begin{array}{c}\text { Plant height } \\
(\mathbf{c m})\end{array}$ & $\begin{array}{c}\text { Root length } \\
(\mathbf{c m})\end{array}$ & $\begin{array}{c}\text { Fresh wt. } \\
(\mathbf{g})\end{array}$ & $\begin{array}{c}\text { Dry wt. } \\
(\mathbf{g})\end{array}$ & Leaves no. \\
\hline R 0.5 & $27.55 \pm 0.22 \mathrm{ef}$ & $14.46 \pm 0.15 \mathrm{~d}$ & $6.76 \pm 0.15 \mathrm{def}$ & $1.92 \pm 0.07 \mathrm{~d}$ & $7.66 \pm 0.33^{\mathrm{a}}$ \\
R 1 & $26.87 \pm 0.13 \mathrm{~g}$ & $13.78 \pm 0.14 \mathrm{e}$ & $6.16 \pm 0.09 \mathrm{fg}$ & $1.34 \pm 0.09 \mathrm{f}$ & $8.00 \pm 1 \mathrm{a}$ \\
R 1.5 & $26.10 \pm 0.1 \mathrm{~h}$ & $13.07 \pm 0.07 \mathrm{f}$ & $5.67 \pm 0.08 \mathrm{~g}$ & $0.94 \pm 0.06 \mathrm{~g}$ & $7.00 \pm 1 \mathrm{a}$ \\
Mean & $27.64 \pm 1.57 \mathrm{c}$ & $14.46 \pm 1.37 \mathrm{c}$ & $6.78 \pm 1.17 \mathrm{c}$ & $1.85 \pm 0.89 \mathrm{c}$ & $7.58 \pm 1.16 \mathrm{a}$ \\
L 0.5 & $28.81 \pm 0.1 \mathrm{c}$ & $15.26 \pm 0.13 \mathrm{bc}$ & $7.35 \pm 0.18 \mathrm{~cd}$ & $2.30 \pm 0.14 \mathrm{c}$ & $8.00 \pm 0.57 \mathrm{a}$ \\
L 1 & $27.87 \pm 0.23 \mathrm{de}$ & $14.80 \pm 0.1 \mathrm{bc}$ & $6.91 \pm 0.08 \mathrm{de}$ & $2.01 \pm 0.01 \mathrm{~d}$ & $7.66 \pm 0.33 \mathrm{a}$ \\
L 1.5 & $27.18 \pm 0.17 \mathrm{fg}$ & $14.28 \pm 0.15 \mathrm{de}$ & $6.51 \pm 0.08 \mathrm{ef}$ & $1.64 \pm 0.11 \mathrm{e}$ & $7.66 \pm 0.88 \mathrm{a}$ \\
Mean & $28.48 \pm 1.16 \mathrm{~b}$ & $15.22 \pm 0.91 \mathrm{~b}$ & $7.32 \pm 0.84 \mathrm{~b}$ & $2.28 \pm 0.62 \mathrm{~b}$ & $7.75 \pm 0.87 \mathrm{a}$ \\
S 0.5 & $29.91 \pm 0.2 \mathrm{ab}$ & $16.15 \pm 0.14 \mathrm{a}$ & $8.25 \pm 0.21 \mathrm{ab}$ & $3.03 \pm 0.03 \mathrm{ab}$ & $8.00 \pm 0 \mathrm{a}$ \\
S 1 & $29.39 \pm 0.23 \mathrm{ab}$ & $15.39 \pm 0.19 \mathrm{ab}$ & $7.77 \pm 0.13 \mathrm{bc}$ & $2.83 \pm 0.1 \mathrm{~b}$ & $7.66 \pm 0.66 \mathrm{a}$ \\
S 1.5 & $28.26 \pm 0.13 \mathrm{~d}$ & $15.07 \pm 0.07 \mathrm{bc}$ & $7.21 \pm 0.12 \mathrm{~cd}$ & $2.46 \pm 0.02 \mathrm{c}$ & $8.00 \pm 0.57 \mathrm{a}$ \\
Mean & $29.40 \pm 0.79 \mathrm{a}$ & $15.78 \pm 0.67 \mathrm{a}$ & $7.94 \pm 0.61 \mathrm{a}$ & $2.88 \pm 0.3 \mathrm{a}$ & $7.83 \pm 0.72 \mathrm{a}$ \\
Control & $30.06 \pm 0.19 \mathrm{a}$ & $16.53 \pm 0.25 \mathrm{a}$ & $8.53 \pm 0.34 \mathrm{a}$ & $3.19 \pm 0.07 \mathrm{a}$ & $7.66 \pm 0.33 \mathrm{a}$ \\
\hline
\end{tabular}

Mean \pm standard error based on ANOVA analysis. Means in the same raw followed by the same letter in each column are not significantly different from each other at the 5\% probability level (p value at $0.05)$ according to Duncan Multiple Range Test (DMRT). R: root; L: leaf; S: seed

Fresh and dry weights of both plants follow the same approach as for the plant height and root length. Relative to control, root powder at concentration $1.5 \%$ showed the greatest reduction of fresh weight of both plants. The lowest fresh weight of broad bean 
was $6.01 \mathrm{~g}$ while the highest value was $9.58 \mathrm{~g}$ observed in control (Table 2). In common beans, the lowest fresh weight was $5.67 \mathrm{~g}$ while the highest value was $8.53 \mathrm{~g}$ which was found in control (Table 3). The highest dry weight of broad and common beans were 3.75 and $3.19 \mathrm{~g}$ observed in control while the lowest values 1.13 , and $0.94 \mathrm{~g}$ respectively were found in pots with $1.5 \%$ root powder.

The data recorded in beans revealed that the greatest reduction in the previous parameters was observed when roots of black nightshade were applied then the leaves while seeds had limited influence. It is suggested to indicate that the measured properties were not significantly different from the control after treated with seed residues this may be attributed to that this organ has the smallest amount of alkaloid.

For the number of leaves, there was no significant difference between different powders treated with different rates in the soil of both plants $(p>0.05)$. The results showed that the incorporated powders of S. nigrum into the soil at rates $0.5,1$, and $1.5 \%$ did not affect the number of leaves of broad and common beans.

The results of yield components of beans were recorded in Table 4. All applied powders of black nightshade incorporated into the soil $(0.5,1$, and $1.5 \%)$ significantly decreased all yield components except the seed powder. Root and leaf powders of black nightshade produced lower yield components than control. Therefore, it could be concluded that $S$. nigrum roots and leaves residues (at $0.5,1$, and $1.5 \%$ ) incorporated into soil caused a reduction in the yield of broad and common beans.

Table 4. Effect of different residues concentrations of black nightshade on the yield of broad and common beans

\begin{tabular}{c|c|c|c|c|c|c}
\hline \multirow{2}{*}{$\begin{array}{c}\text { Treatments } \\
(\%)\end{array}$} & \multicolumn{3}{|c|}{ Broad bean } & \multicolumn{3}{c}{ Common bean } \\
\cline { 2 - 7 } & No. of pods & No. of seeds & $\begin{array}{c}\text { Wt. of 100 } \\
\text { seeds (g) }\end{array}$ & No. of pods & No. of seeds & $\begin{array}{c}\text { Wt. of 100 } \\
\text { seeds }(\mathbf{g})\end{array}$ \\
\hline R 0.5 & $5.71 \pm 0.19 \mathrm{~d}$ & $3.42 \pm 0.16 \mathrm{~cd}$ & $79.63 \pm 0.77 \mathrm{c}$ & $7.91 \pm 0.13 \mathrm{~b}$ & $4.95 \pm 0.06 \mathrm{c}$ & $35.23 \pm 0.12 \mathrm{c}$ \\
R 1 & $4.27 \pm 0.21 \mathrm{e}$ & $2.66 \pm 0.11 \mathrm{e}$ & $75.86 \pm 0.26 \mathrm{~d}$ & $6.86 \pm 0.22 \mathrm{~d}$ & $4.02 \pm 0.18 \mathrm{~d}$ & $32.56 \pm 0.31 \mathrm{~d}$ \\
R 1.5 & $3.27 \pm 0.14 \mathrm{f}$ & $1.85 \pm 0.10 \mathrm{f}$ & $72.38 \pm 0.14 \mathrm{e}$ & $6.10 \pm 0.05 \mathrm{e}$ & $3.28 \pm 0.17 \mathrm{e}$ & $30.66 \pm 0.17 \mathrm{e}$ \\
Mean & $5.15 \pm 1.64 \mathrm{c}$ & $3.06 \pm 0.98 \mathrm{c}$ & $77.79 \pm 4.31 \mathrm{c}$ & $7.45 \pm 1.14 \mathrm{c}$ & $4.43 \pm 0.93 \mathrm{~b}$ & $37.62 \pm 0.4 \mathrm{a}$ \\
L 0.5 & $6.30 \pm 0.25 \mathrm{c}$ & $3.80 \pm 0.10 \mathrm{bc}$ & $81.46 \pm 0.4 \mathrm{~b}$ & $8.17 \pm 0.09 \mathrm{~b}$ & $5.05 \pm 0.04 \mathrm{bc}$ & $36.13 \pm 0.20 \mathrm{~b}$ \\
L 1 & $5.69 \pm 0.21 \mathrm{~d}$ & $3.08 \pm 0.04 \mathrm{de}$ & $79.67 \pm 0.66 \mathrm{c}$ & $7.38 \pm 0.19 \mathrm{c}$ & $4.28 \pm 0.22 \mathrm{~d}$ & $34.73 \pm 0.37 \mathrm{c}$ \\
L 1.5 & $4.30 \pm 0.15 \mathrm{e}$ & $2.18 \pm 0.10 \mathrm{f}$ & $74.98 \pm 0.19 \mathrm{~d}$ & $6.65 \pm 0.18 \mathrm{~d}$ & $3.79 \pm 0.14 \mathrm{de}$ & $32.63 \pm 0.18 \mathrm{~d}$ \\
Mean & $5.91 \pm 1.2 \mathrm{~b}$ & $3.34 \pm 0.86 \mathrm{~b}$ & $79.85 \pm 3.29 \mathrm{~b}$ & $7.78 \pm 0.92 \mathrm{~b}$ & $4.65 \pm 0.74 \mathrm{~b}$ & $37.62 \pm 0.4 \mathrm{a}$ \\
S 0.5 & $7.05 \pm 0.07 \mathrm{ab}$ & $4.27 \pm 0.12 \mathrm{a}$ & $82.33 \pm 0.25 \mathrm{a}$ & $8.01 \pm 0.06 \mathrm{a}$ & $5.04 \pm 0.17 \mathrm{a}$ & $37.90 \pm 0.09 \mathrm{a}$ \\
S 1 & $6.68 \pm 0.24 \mathrm{bc}$ & $3.98 \pm 0.01 \mathrm{ab}$ & $83.08 \pm 0.11 \mathrm{a}$ & $8.10 \pm 0.13 \mathrm{a}$ & $5.12 \pm 0.27 \mathrm{ab}$ & $37.66 \pm 0.1 \mathrm{a}$ \\
S 1.5 & $6.98 \pm 0.21 \mathrm{ab}$ & $4.14 \pm 0.22 \mathrm{ab}$ & $82.44 \pm 0.31 \mathrm{a}$ & $8.03 \pm 0.13 \mathrm{a}$ & $4.39 \pm 0.27 \mathrm{abc}$ & $36.3 \pm 0.17 \mathrm{a}$ \\
Mean & $7.02 \pm 0.38 \mathrm{a}$ & $4.18 \pm 0.27 \mathrm{a}$ & $83.33 \pm 0.39 \mathrm{a}$ & $8.96 \pm 0.18 \mathrm{a}$ & $5.58 \pm 0.4 \mathrm{a}$ & $37.62 \pm 0.4 \mathrm{a}$ \\
Control & $7.36 \pm 0.2 \mathrm{a}$ & $4.32 \pm 0.19 \mathrm{a}$ & $83.29 \pm 0.21 \mathrm{a}$ & $8.93 \pm 0.11 \mathrm{a}$ & $5.49 \pm 0.25 \mathrm{abc}$ & $37.62 \pm 0.39 \mathrm{a}$ \\
\hline
\end{tabular}

Mean \pm standard error based on ANOVA analysis. Means in the same raw followed by the same letter in each column are not significantly different from each other at the 5\% probability level (p value at 0.05) according to Duncan Multiple Range Test (DMRT). R: root; L: leaf; S: seed

\section{Discussion}

The high nutritional value and protein content make broad and common beans, belonging to the family Leguminosae, the most important crops in the world, especially in developing countries. Weeds cause a substantial decline in agriculture production 
through direct and indirect effects. Therefore, it is important to determine the effect of these weeds on the growth of crops. Also, S. nigrum is distributed in some field crops in Egypt.

According to the displaying data, black nightshade affects germination, growth, and yield of beans negatively. The probable reason for S. nigrum potent allelopathic activity may be due to the presence of many bioactive secondary metabolites in this plant, particularly alkaloids which are responsible for suppressing the growth of other plants (Sabh and Ali, 2010). The inhibitory effect on yield and yield parameters is directly proportional to the increase in the concentration used and this might be due to the presence of toxic allelochemicals like alkaloids. According to Girija and Gowri (2008) the leaf, and fruit extracts of $S$. nigrum contain alkaloids, that may suppress the germination, radicle length, and total protein content of P. sativum, E. coracona, and $T$. foenum.

Eltayeb et al. (1997) reported that solasodine occurs in roots, stems, leaves, and fruits of $S$. nigrum. The lowest levels are registered in stems and the highest in leaves. In vegetative organs, and particularly in roots, absolute amounts of solasodine rise steadily with age but decrease in fruit. From the results obtained, we found that the root of $S$. nigrum had the strongest allelopathic effect on germination, yield, and growth parameters compared to leaves, and seeds. Likewise, Imad et al. (2017) found that the alkaloidal content of plant parts changes during the development of $S$. nigrum, the absolute amount of alkaloid per leaf increased during leaf development, whereas the concentration declined. Both the concentration and the absolute amount of solasodine per fruit decrease with fruit maturation. Generally, Debnath et al. (2016) found that leaves aqueous extract exhibit more allelopathy for seedlings than those from the flowers of $S$. sisymbrifolium (Lam.) on $V$. radiata, A. mangostanus, and B. campestris, whereas it is less effective on $O$. sativa. However, the leachates extracted at the flowering stage from $N$. plumbaginifolia provided the greatest growth inhibition and biochemical parameters for seedlings of sunflower depending on concentration (Singh et al., 2015). Also, Morais et al. (2013) displayed that ethanol extract and fractions obtained from ripe fruits of $S$. lycocarpum showed allelopathic potential on the growth of onion radicles; inhibitory effect on the growth of hypocotyls, and radicles of lettuce. The results of germination and pot experiments showed a great reduction increased with the concentration of allelopathic plant, this agrees with Bosch et al. (2004) who showed that leaf leachates of $S$. mauritianum (Scop.) reduced germination in $H$. stricta in a concentration-dependent manner. The growth of both beans was suppressed and radicle and plumule length were decreased, these may be attributed to the allelochemicals which disrupt the growth hormones. El-Shora et al. (2015) found that radicle and plumule of fenugreek, a medicinal plant showed a sensitive response to allelochemicals from aqueous extracts which might have interfered with hormones that encourage growth, development, cell elongation, and cell division especially on younger active root tips.

All growth parameters, plant height, root length, fresh and dry weights except number of leaves reduced after applying root and leaf residues in soil. Allelochemicals from leachates of $S$. nigrum might have interfered with photosynthesis leading to drastic changes in the physiology of plants. El-Shora et al. (2018) found that the decline in photosynthesis may have contributed to decreased growth of plants and decreased accumulation of fresh biomass due to decreased water content in the species studied. In this regard, Fikreyesus et al. (2011) reported that tomato root elongation was inhibited 
by extracts of Eucalyptus camandulensis, and Gulzar et al. (2014) observed that the root length of $C$. album, $M$. alba, and $N$. plumbaginifolia decreased as the concentration of $C$. sophere increased. The results of the study are consistent with Hamidi et al. (2008) who observed the allelopathic ability of $H$. spontaneum residues incorporated into the soil on the length of seedling, and the dry weight of $T$. aestivum. Also, Ismail and Siddiqui (2011) found that seedling length and weight of $O$. sativa were suppressed by residues of $C$. iria. The greatest reduction in growth parameters was observed at $1.5 \%$ concentration residue of $S$. nigrum, and this was consistent with the results of Zohaib et al. (2014) who found that the inhibitory effects of five leguminous weeds against rice caused by the highest concentration of water extracts and residues of these weeds.

\section{Conclusion}

Allelopathy can cause substantial decline in the growth and yield of crops. This study was devoted to determining the allelopathic effects of different parts of black nightshade on some leguminous crops, broad and common beans. According to the results of germination and pot experiments, it was found that roots of black nightshade had the highest inhibitory effect on beans. Germination, growth parameters except for the number of leaves and yield exhibited a high level of inhibition by the highest concentration of roots. While seeds showed a limited influence on these parameters. The decline of growth and yield requires further studies on the germinated seeds related to the biosynthesis of secondary metabolites at molecular level. The results confirmed that $S$. nigrum has an allelopathic effect on broad and common beans which depends on plant parts and concentration used in the extract preparation.

Acknowledgements. The authors acknowledge of the Zagazig University, Faculty of Science, Department of Botany and Microbiology for providing laboratory facilities and helping in analytical procedures of the research work.

\section{REFERENCES}

[1] Bosch, E. V. D., Ward, B. G., Clarkson, B. D. (2004): Woolly nightshade (Solanum mauritianum) and its allelopathic effects on New Zealand native Hebe stricta seed germination. - New Zealand Plant Protection 57: 98.

[2] Chen, R., Feng, L., Li, H., Zhang, H., Yang, F. (2009): Two novel oligosaccharides from Solanum nigrum. - Carbohydrate Research 344: 1775-1777.

[3] Debnath, B., Debnath, A., Paul, C. (2016): Allelopathy effects of invasive weed on germination and seedling growth of four widely cultivated Indian crops. - International Journal of Science and Nature 7: 194-198.

[4] Edeoga, H. O., Okwu, D. E., Mbaebie, B. O. (2005): Phytochemical constituents of some Nigerian medicinal plants. - Journal of Biotechnology 4: 685- 688.

[5] Elakovich, S. D. (1987): Sesquiterpenes as phytoalexins and allelopathic agents. Ecology and Metabolism of Plant Lipids 7: 93-108.

[6] EL-Shora, H. M., EL-Farrash, A. H., Kamal, H., Abdelzarek, A. (2015): Enhancement of antioxidant defense system by UV-Radiation in fenugreek as a medicinal plant. International Journal of Advanced Research 3: 529-535.

[7] EL-Shora, H. M., Ahmed, M. A., Ahmed, M. E., Halas, T. (2018): Influence of Datura Stramonium leaf extract on antioxidants and activities of metabolic enzymes of 
Trigonella foenum-graecum and Lepidium sativum. - International Journal of Current Research and Academic Review 6: 1-11.

[8] Eltayeb, E. A., Al-Ansari, A. S., Roddick, J. G. (1997): Changes in the steroidal alkaloid solasodine during the development of Solanum nigrum and Solanum incanum. Phytochemistry 46: 489-494.

[9] Fikreyesus, S., Kebebew, Z., Nebiyu, A., Zeleke, N., Bogale, S. (2011): Allelopathic effects of Eucalyptus camaldulensis Dehnh. on germination and growth of tomato. American-Eurosian J. of Agriculture and Environmental Sciences 11: 600-608.

[10] Fukuhara, K., Kubo, I. (2004): Arudonine, an allelopathic steroidal glycoalkaloid from the root bark of Solanum arundo Mattei. - Phytochemistry 65: 1283-1286.

[11] Girija, G., Gowri, S. (2008): Allelopathic effect of Solanum nigrum on Pisum sativum, Eleusine coracana and Trigonella foenum graecum. - Biomedical and Pharmacology Journal 1: 185-194.

[12] Gulzar, A., Siddiqui, M. B., Shazia, B. (2014): Assessment of allelopathic potential of Cassia sophera L. on seedling growth and physiological basis of weed plants. - African Journal of Biotechnology 13: 1037-1046.

[13] Hadi, M. Y., Hameed, I. H., Ibraheam, I. A. (2017): Ceratonia siliqua: characterization, pharmaceutical products and analysis of bioactive compounds. A review. - Research Journal of Pharmacy and Technology 10: 3585-3589.

[14] Hamidi, R., Mazaheri, D., Rahimian, H., Alizadeh, H. M., Ghadiri, H., Zeinali, H. (2008): Phytotoxicity effect of soil amended residues of wild barley (Hordeum spontaneum Koch) on growth and yield of wheat (Triticum aestivuum L.). - Desert 13: 1-7.

[15] Imad, H. H., Maria Rosario, C., Mohammed, Y. H. (2017): A review: Solanum nigrum L. antimicrobial, antioxidant properties, hepatoprotective effects and analysis of bioactive natural compounds. - Research J. of Pharmacy and Technology 10: 4063-4068.

[16] Ismail, B. S., Siddique, M. A. B. (2011): The inhibitory effect of grass hoppers Cyprus (Cyperus iria $\mathrm{L}$.) on the seedling growth of five Malaysian rice varieties. - Tropical Life Science Research 22: 81-89.

[17] Mohsin, N., Tariq, M., Zaki, M. J., Abbasi, M. W., Imran, M. (2016): Allelopathic effect of Ficus benghalensis L. leaves extract on germination and early seedling growth of maize, mungbean and sunflower. - International Journal of Biological Research 4: 34-38.

[18] Morais, M. G., Silva, V. D., Oliveira, G. T., Ferreira, J. M. S., Lima, L. A. (2013): Allelopathic potential of the ripe fruits of Solanum lycocarpum A. St. Hil. (Solanaceae). Biochemistry and Biotechnology Reports 2: 37-41.

[19] Mushtaq, W., Siddiqui, M. B. (2018): Allelopathy in solanaceae plants. - Journal of Plant Protection Research 58: 1-7.

[20] Obadoni, B. O., Ochuko, P. O. (2001): Phytochemical studies and comparative efficacy of the Crude extracts of some homeostatic plants in Edo and Delta States of Nigeria. Global J. of Pure Applied Science 8: 203-208.

[21] Sabh, A. Z., Ali, I. H. (2010): Allelopathic activity of nightshade (Solanum nigrum L.) on seedling growth of certain weeds and crops. - Annals of Agricultural Science 55: 87-94.

[22] Singh, A., Singh, D., Singh, N. B. (2015): Allelopathic activity of Nicotiana plumbaginifolia at various phenological stages on sunflower. - Allelopathy Journal 36: 315-325.

[23] Srisawat, U., Panuto, W., Kaendee, N., Tanuchit, S., Itharat, A., Lerdvuthisopon, N., Hansaku, P. (2010): Determination of phenolic compounds, flavonoids, andantioxidant activities in water extracts of Thai red and white rice cultivars. - Journal of Medical Association Thailand 93: 83-91.

[24] Stef, R., Butu, B. C., Ortan, A., Steliana, A., Butu, M. (2013): Comparative characteristics of Lupinus perennis L. under allelochemical sorgoleone stress. Romanian Biotechnological Letters 18: 8327-8332. 
[25] Tahir, J. F. (2011): Weeds control in forest ecosystem by the allelopathic potential of black walnut (Juglans nigra L.). - MSc. Thesis, Coll. of Agric., Duhok Univ., Duhok, Iraq.

[26] Zeng, R. S., Luo, S. M., Shi, Y. H., Tu, C. Y. (2010): Physiological and biomechanical mechanism of allelopathy of secalonic acid on higher plants. - Agronomy J. 93: 72-79.

[27] Zohaib, A. S., Tanveer, A., Safdar, M. E. (2014): Phytotoxic effect of water soluble phenolics from five leguminous weeds on germination and seedling growth of rice. Pakistan J. of Weed Science Research 20: 417-429. 